\title{
Groundwater potentiality assessment in an arid zone using a statistical approach and multi-criteria evaluation, southwestern Tunisia
}

\author{
Mohamed Haythem MSADDEK ${ }^{1, *}$, Dhekra SOUISSI ${ }^{1}$, Yahya MOUMNI ${ }^{1}$, Ismail CHENINI ${ }^{1}$, \\ Nacira BOUAZIZ ${ }^{2}$ and Mahmoud DLALA ${ }^{1}$ \\ 1 UR13ES26, Paléoenvironnement, Géomatériaux et Risques Géologiques, Faculté des sciences de Tunis, Université de \\ Tunis El Manar, 2092, Tunis, Tunisia \\ 2 University of Mouloud Mammeri of Tizi-Ouzou, Laboratory of Geomaterials Environnement and Developing (LGEA), BP \\ $\mathrm{N}^{\circ} 17,15000$, Tizi-Ouzou, Algeria
}

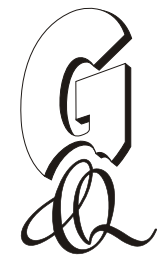

Msaddek, M.H., Souissi, D., Moumni, Y., Chenini, I., Bouaziz, N., Dlala, M., 2019. Groundwater potentiality assessment in an arid zone using a statistical approach and multi-criteria evaluation, southwestern Tunisia. Geological Quarterly, 63 (1): 3-15, doi: $10.7306 / g q .1451$

Associate editor: Tatjana Solovey

\begin{abstract}
The aim of this paper is to assess the groundwater potentiality using statistical multi-criteria evaluation and AHP (analytic hierarchy process) as an additional method to the hydrogeological research in order to create a map that represents the groundwater potentiality. The extraction of this map is based on the study of multi-criteria input data, such as lineaments, land use, lithology, drainage, slope, soil, rainfall and geomorphology. Weights were assigned using the AHP method to all these multi-influencing factors according to their influence on groundwater potential. Sensitivity analysis was calculated to validate the AHP weights result. The presented methodology has been applied to the Bouhedma region in southwestern Tunisia, located in an arid climate. This technique revealed that very good, good, moderate and poor groundwater potentia zones are spread over $382 \mathrm{~km}^{2}(26.9 \%), 437 \mathrm{~km}^{2}(30.7 \%), 552 \mathrm{~km}^{2}(38.8 \%)$ and $51 \mathrm{~km}^{2}(3.6 \%)$, respectively. Furthermore, the effect of each influencing factor on groundwater capacity was computed. The results provide significant information and found to be helpful in better planning and management of groundwater resources.
\end{abstract}

Key words: groundwater assessment, AHP, multi-criteria evaluation, arid zone, Tunisia.

\section{INTRODUCTION}

Groundwater is considered the largest freshwater source in arid regions. It should be studied more minutely regarding its potentiality and evaluation. To ensure sustainable management of water resources, it is important to identify areas where groundwater resupplying is performed (Oikonomidis et al., 2015). Geographic Information Systems (GIS) and Remote Sensing integrated with multi-criteria evaluation can reveal useful tools in groundwater survey mapping to identify groundwater potential zones. Many published papers described the uses of GIS and Remote Sensing to estimate groundwater potentiality by the interaction with surface parameters (Arnold et al., 1993; Harbor, 1994; Finch, 1998; Bouwer, 2002; Sophocleous, 2002; Doell et al., 2012).

In recent years, spread-out use of remotely sensed data from satellite images has made it easier to establish a large and

\footnotetext{
* Corresponding author, e-mail: mmhaythem@gmail.com
}

Received: February 18, 2018; accepted: October 18, 2018; first published online: February 12, 2019 consistent database for groundwater potential zones (Saraf and Choudhury, 1998; Al-Adamat et al., 2003; Becker, 2006; Jha et al., 2007; Machiwal et al., 2011; Selvam et al., 2016). Remote sensing not only provides a specified and clear data of the spatial distribution of observations, but also saves time and money (Ozesmi and Bauer, 2002; Blaschke, 2010; Souissi et al., 2018). In addition, it is widely used to characterize the earth surface (such as lineaments, land use, drainage patterns, slope and geomorphology) as well as to examine the groundwater potential zones (Dasho et al., 2017).

Integration with Geographic Information Systems (GIS) enables an advanced processing of multi-source spatial data. Use of GIS for groundwater potentiality mapping offers the ability to store, manipulate and analyse data in different formats and at different scales (Rahman, 2008), and it is then possible to register all data as data layers with a common coordinate system and manipulate them to produce thematic maps (Hamza et al., 2017).

Many methods and techniques have been applied by many researchers around the world, to determine the groundwater potentiality. Dinesh Kumar et al. (2007) used GIS and Remote Sensing to identify groundwater potential zones. Mukherjee et al. (2012) proposed a method to map potential areas for groundwater storage using GIS and Remote Sensing in arid regions. Magesh et al. (2012) developed a method for groundwa- 


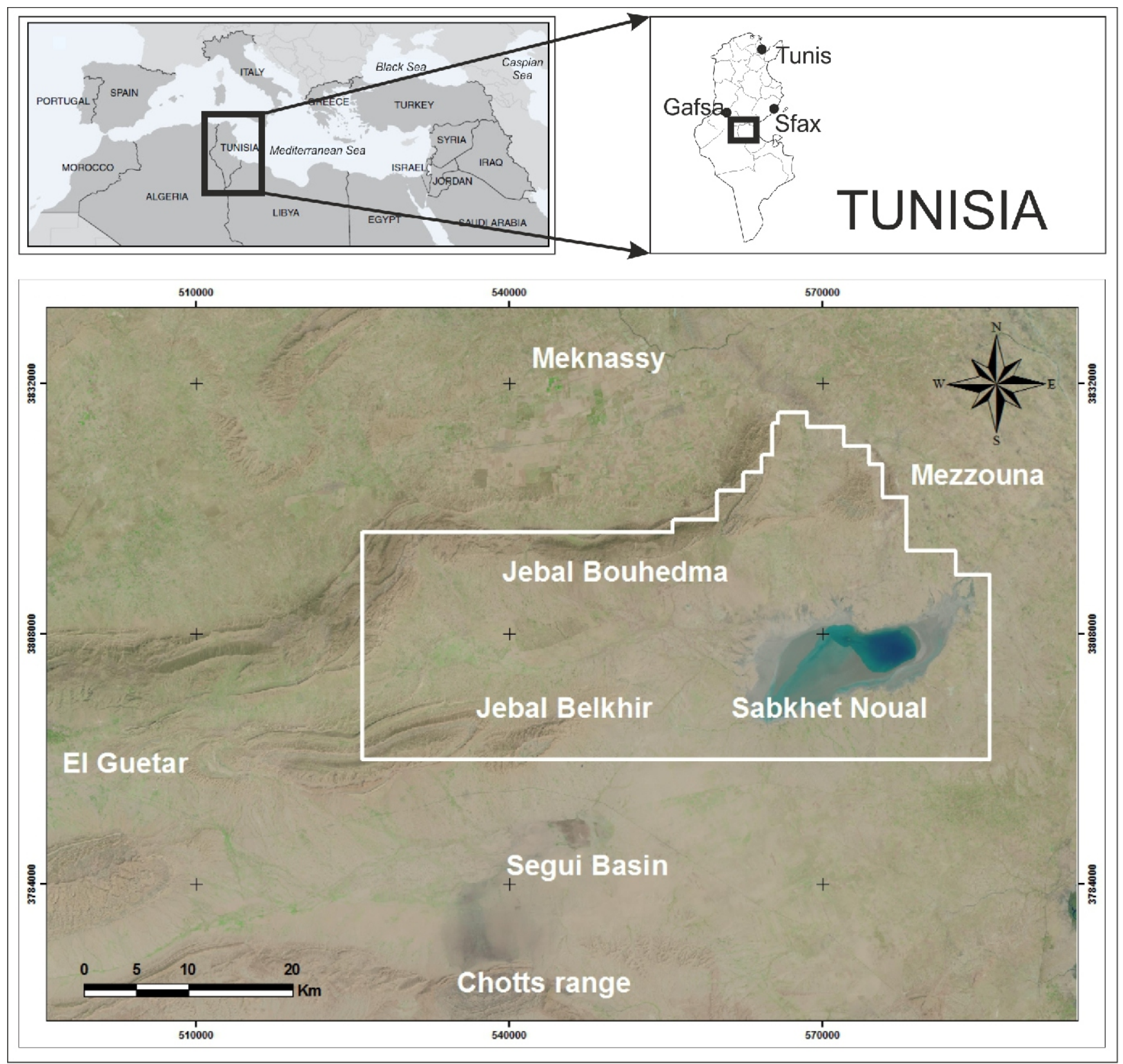

Fig. 1. Location of study area on Landsat-8 OLI/TIRS satellite image

ter potentiality mapping in Theni district, Tamil Nadu (India), taking into account seven influencing factors: lithology, slope, land use, lineament, drainage, soil and rainfall. Fenta et al. (2015) applied a similar method to determine groundwater potentiality of the Raya Valley, northern Ethiopia, using spatial analysis and multi-criteria evaluation.

Several studies currently exist for the investigation and mapping of groundwater potentiality in the arid region in Tunisia (Chenini and Ben Mammou, 2010; Msaddek et al., 2017; Mokadem et al., 2018; Souissi et al., 2018) and in the world (Gustafsson et al., 1993; Al-Adamat et al., 2003; Scanlon et al., 2006; Ghayoumian et al., 2007; Chowdhury et al., 2009; Mukherjee et al., 2012; Naghibi et al., 2018).

This paper presents the investigation and mapping of groundwater potentiality of the Bouhedma region located in southwestern Tunisia by integration of further influencing factors and multi-criteria evaluation to the previously applied meth- ods (Oikonomidis et al., 2015) with the contribution of the weighted linear combination method (WLC) and the analytic hierarchy process (AHP; Saaty, 1980). Therefore, integration of remote sensing with GIS for preparing various thematic layers, such as lineaments, land use, lithology, drainage, slope, soil, rainfall and geomorphology with assigned weightage, rate and score, will assist the identification of potential groundwater zones.

\section{STUDY AREA}

The study area is located in southwestern Tunisia, in the region of Bouhedma, occupying an area of $1,422 \mathrm{~km}^{2}$ (Fig. 1). The geomorphology of the region is characterized by weak to relatively high relief with the elevations from 7 to $903 \mathrm{~m}$. The climate is arid and characterized by dry and hot summers, and 

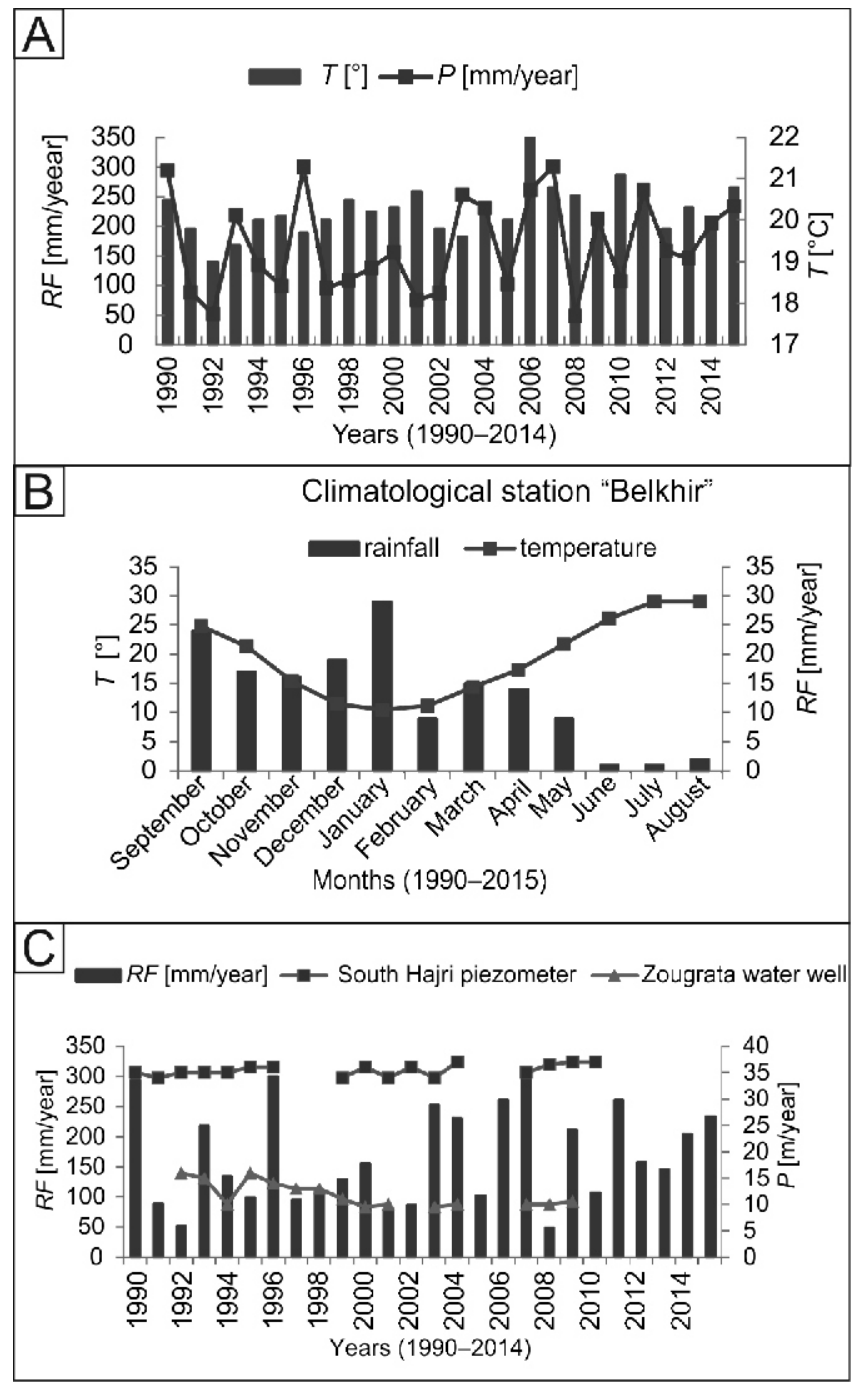

Fig. 2A - correlation rainfall-temperature-years; B - monthly rainfall-temperature-years at the climatological "Belkhir" station between 1990 and 2015; C - correlation rainfall-piezometric variability in the Zougrata water well and the South Hajri piezometer

wet and mild winters (Fig. 2A). The average temperature is $20.2^{\circ} \mathrm{C}$, with the maximum in August $\left(28.7^{\circ} \mathrm{C}\right)$ and the minimum in January $\left(11.5^{\circ} \mathrm{C}\right.$; Fig. $\left.2 \mathrm{~A}\right)$. The average annual rainfall in the district is $\sim 250 \mathrm{~mm}$. The analysis of the results (Fig. 2B) shows that the monthly rainfall distribution during the period from 1990 to 2015 is seasonal and irregular. The actual evapotranspiration (AET) estimated by the Turc method is $\sim 207 \mathrm{~mm} /$ year. The analysis of Figure $2 \mathrm{C}$ shows that the piezometric level in the South Hajri piezometer and the Zograta water well increases progressively according to the rainfall during the rainy years (1990-1995-1996-2000-2005-2009).

At 2015, the annual water resources of the Miocene aquifer were estimated at $2.5 \mathrm{Mm}^{3}$. The annual exploitation is about $0.37 \mathrm{Mm}^{3} /$ year with an exploitation rate equal to $14.8 \%$ in 2015 (Msaddek, 2017). This weak rate is due to the lack of understanding the groundwater potential in this region.

Land use is mainly agricultural in lowlands and the use of groundwater for drinking and irrigation has increased during the last decades (Mamou, 1990; Bencheikh, 2013; Msaddek, 2017).

The population is low; it does not exceed 10,000 inhabitants. The average density of population is around 7 inhabitants $/ \mathrm{km}^{2}$. Due to the arid climate and freshwater scarcity, the main economic activity is limited to artisanal agriculture, such as animal husbandry and dryland farming.

The drainage network of the Bouhedma region is relatively simple because of its morphology. In fact, it is a deep basin, surrounded by high mountains, which means that the rainwater cannot be obtained easily. The alluvial basin owes its groundwater to different rivers, which cross the area. They receive adequate supply during winter rainfall, especially in mountain heights, mainly upstream of the rivers. The central part of the Bouhedma basin has received the effect drainage network. The southern part of the basin is occupied by a large salt lake called Sabkhet Noual. It is considered the downstream of the drainage network, at the exit from the mountain complex.

Concerning its geology and lithology, the study area belongs to the Southern Atlas range. The majority of anticlines in this region have an E-W to ENE-WSW axial direction (Ahmadi, 2006; Msaddek et al., 2016). Major faults of the study area represent branches of the South Atlas front that separates the Atlas chain and the Saharan Platform. These faults dominate the geological structures of the region (Zargouni, 1985; Zouari, 1995; Ahmadi, 2006; Msaddek et al., 2016). In the northern part of the study area, there is a range of Jebal Orbata and Jebal Bouhedma stretching along $70 \mathrm{~km}$. El Mech junction relates these two mountains. In the southwestern part of the study area, there are two linked structures, Jebal Chamsi and Jebal Belkhir, $58 \mathrm{~km}$ in length. Jurassic to Quaternary rocks are outcropped in the study area. They are dominated by Mio-PlioQuaternary sandy and detrital deposits and by Lower and Upper Cretaceous and Eocene carbonates (Henchiri, 2007; Zouaghi et al., 2011, Kadri et al., 2015). The geological bedrock consists of clay and marls, which are almost impermeable. Sands, conglomerates and detrital deposits of the alluvial area are 400-500 $\mathrm{m}$ thick and their permeability factor is high. The main aquifer systems are developed within Mio-Plio-Quaternary formations. These deposits are present in the majority of the area.

There are not many hydrogeological data reports and studies except for the works of Mamou (1990), Bencheikh (2013), Msaddek (2017), and other unpublished local reports. This encourage authors to study the groundwater potential in this region with the contribution of the weighted linear combination method (WLC) and the analytic hierarchy process (AHP).

\section{DATA SOURCE AND METHODS}

\section{DATA COLLECTION AND PROCESSING}

This study uses mainly multi-criteria analysis of different parameters based on Remote Sensing, Geographic Information System (GIS) and SRTM (Shuttle Radar Topography Mission) data to evaluate groundwater potentiality. We used geological maps of the study area from the Tunisian National Office of Mines (ONM) at 1:100,000 scale. The remotely sensed data were extracted from a Landsat-8 OLI/TIRS satellite image, taken on April $12^{\text {th }}, 2015$. The digital elevation model (DEM) was obtained from images of the American Topographic Mission (SRTM30-1Arc second) defined with a mesh of $30 \times 30 \mathrm{~m}$ (Hegazy and Effat, 2010).

Meteorological, climatological, geological and pedological data were vectorized by the General Department of Water Resources (DGRE) and used to establish thematic maps.

All pre-treatment and processing of the Landsat-8 OLI/TIRS image were executed by means of ENVI 5.1 software (Environment for visualizing image) and PCI GEOMATICA 2015 software (Focus 2015). 


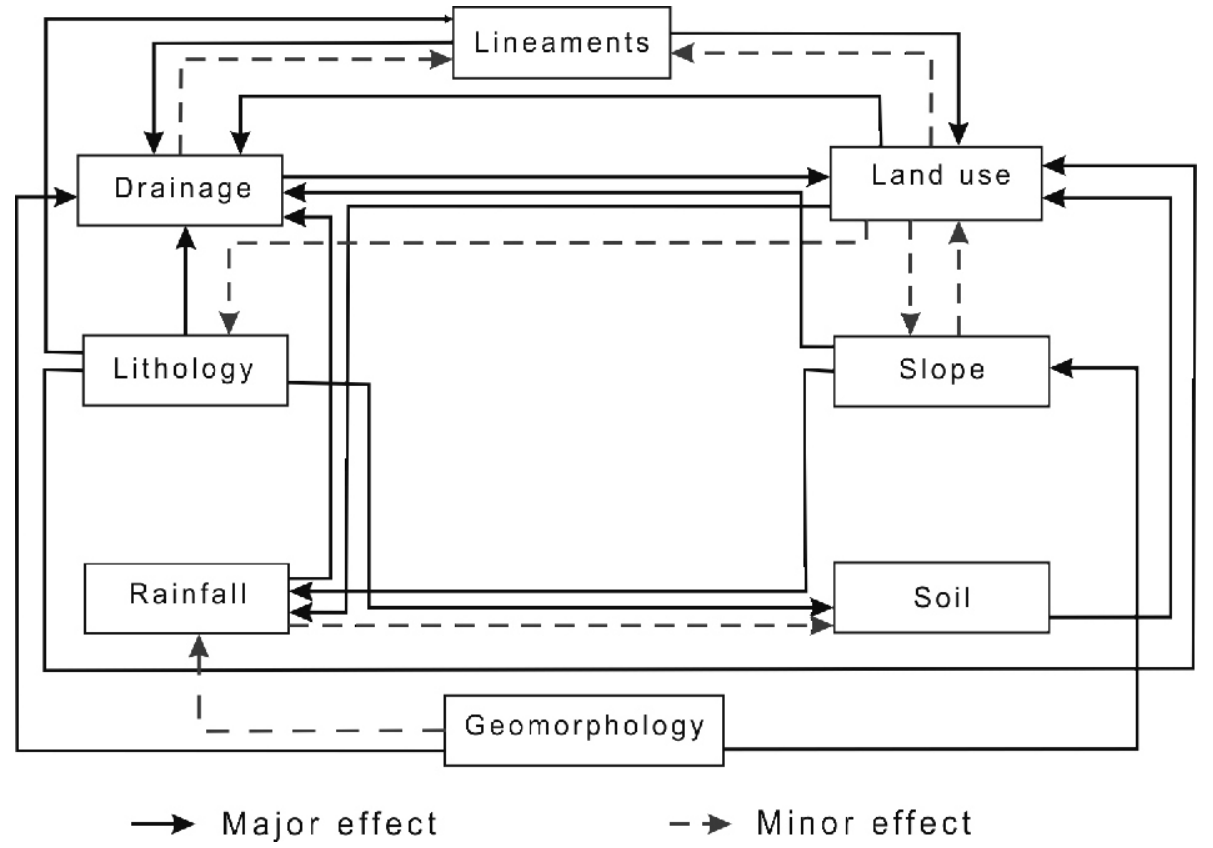

Fig. 3. The interactive influence of factors concerning groundwater potential (Shaban et al., 2006; Magesh et al., 2012)

ArcGIS 10.2.2 software enabled data vectorization and SRTM processing. It was used to superimpose data layers and to compile different maps. It was involved to interpolate different maps of spatial variation (density maps).

\section{PREPARATION OF THE GIS LAYER}

To determine the groundwater potential zone, the weights of different factors for groundwater potential and the score under various characteristics were assessed based on the characteristics of the Bouhedma basin. The factors influencing groundwater potential, and their relative importance, are compiled from previous papers (Yeh et al., 2009). Duplicate factors were combined and only representative factors were extracted. This study uses lineaments, land use, lithology, drainage, slope, soil, rainfall and geomorphology as the eight-significant factors influencing groundwater potential.

First of all, a multi-influencing factors method was used considering the interactive influence and interrelationship between these factors, and their effect is shown in Figure 3. Each relationship is weighted according to its potency. The representative weight of a factor of the potential zone is the sum of all weights from each factor (Magesh et al., 2012). A factor with a higher weight value shows a larger impact, and a factor with a lower weight value shows a smaller impact on groundwater potential zones. Integration of these factors with their potential weights is computed through weighted overlay analysis.

To establish the lineaments map of the study area, we applied semi-automatic extraction from the Landsat-8 OLI/TIRS image using the combination of different spectral bands (including panchromatic band) and lineaments enhancement by filtering, and the evaluation and validation of extracted lineaments from image digital treatment using the digital elevation model of SRTM and field verification to eliminate non-tectonic lineaments. Lineaments density calculation proceeded by consideration of surface unit $\left(\mathrm{km}^{2}\right)$. The measurement was performed by an interpolation method of cubic convolution (Masoud and Koike, 2006; Yao, 2009).
To interpret results of extracted lineaments, we used statistical methods based on coupling of measurements of lineaments direction and density, using Equation 1.

$$
L D=\frac{\sum_{i-1}^{i=n} L i}{U a}
$$

where: $\Sigma L i-$ the total length of all lineaments within the study area $(\mathrm{km})$, and $U a-$ a unit area $\left(L^{2}=\mathrm{km}^{2}\right)$.

Land use is an important factor in the study of groundwater potential. It includes the type of soil, the distribution of residential areas, and vegetation cover. Leduc et al. (2001) estimated the difference in the amount of groundwater potential due to changes in land use and vegetation.

Land use map was established by the same remotely sensed data from Landsat-8 images using the principal component analysis (PCA) based on analysis of image covariance or correlation matrix of several data series (Davidson and Ben-David, 2011) and the supervised classification techniques.

The lithology layer was prepared from the existing maps obtained from the Tunisian National Office of Mines (ONM).

The drainage network was extracted from the digital elevation model of SRTM of the study area. In order to convert the drainage network pattern to a measurable quantity, drainage density was used.

The drainage density is defined as a ratio of the total length of streams within a basin to the total area of the basin. A high value of the drainage density would indicate a rapid storm response (Rahmati et al., 2016). The drainage density $(D D)$ for each sub-watershed was calculated by using Equation 2 (Agarwal, 1998; Rahmati et al., 2016):

$$
D D=\frac{\sum_{i=1}^{i=n} D i}{U a}
$$


where: $\Sigma D i$ - the total length of all streams within the study area $(\mathrm{km})$, and $\mathrm{Ua}$ - a unit area $\left(D^{2}=\mathrm{km}^{2}\right)$.

When the drainage density value of a sub-watershed is high, it is indicative of high flood hazard potential.

Slope map was obtained from automatic geospatial processing of the SRTM digital elevation model. These data were spatially interpolated using the Inverse Distance Weighted (IDW) method. This interpolation method combines the concepts of proximity to follow Thiessen polygons with gradual change of the trend surface (Magesh et al., 2012).

Soil layer was prepared from the existing maps obtained from the Tunisian National Office of Mines (ONM) and the General Department of Water Resources (DGRE).

Rainfall layer was prepared from the existing maps obtained from the General Department of Water Resources (DGRE).

Geomorphology map was obtained from the output raster DEM (Digital Elevation Model) generated within the boundary of the study area and with a specified output cell size. The spatial resolution is chosen depending on the scale and purpose of the analysis.

It consists of the dependency of results on the illumination azimuth when the shaded relief is used for lineaments extraction (Šilhavý et al., 2016). To avoid this azimuth partiality, we combined illuminated input raster data into one output raster. The roughness of the shaded reliefs is used as an asset in the adopted method. The illuminated shaded reliefs are used to pull out different results that are processed separately.

The cartographic projection applied to the study area is the World Geodesic System (WGS-84) zone 32 of the Northern Hemisphere with UTM projection.

\section{WEIGHTING METHOD TO IDENTIFY GROUNDWATER POTENTIAL MAP}

To enhance the delineation of the groundwater potential zone, a weighted spatial analysis method was applied for identifying groundwater potential zones, according to their relevance to the existence of groundwater. Eventually, a groundwater potentiality map was created (using layer reclassification and weighted overlay of spatial analysis by ArcGIS software), consisting of four gradational potentiality classes, ranging from poor to very good.

The mathematical weighted linear combination method (WLC; Saaty, 1980) was used to derive the final groundwater potentiality map and to calculate the groundwater potentiality index in accordance with the mathematical Equation 3:

$$
I p=\sum l x_{w} \times x_{r}
$$

$x$ - influencing factors; the subscripts $w$ and $r$ indicate weights and rates, respectively.

$I p=I I n_{w} I I n_{r}+l u s_{w} l u s_{r}+I I i_{w} I I i_{r}+I d r_{w} I d r_{r}+I s I_{w} I s I_{r}+I s o_{w} I s o_{r}+I I f_{w} I r f_{r}+$ $\operatorname{lgm}_{w} \operatorname{lgm}_{r}$

where: $I p$ - groundwater potential index is the value for each pixel of the final groundwater potentiality map of the study area; IIn - lineaments index; lus - land use index; Ili - lithology index; Idr - drainage index; IsI - slope index; Iso - soil index; Irf - rainfall index; Igm geomorphology index

The influence of weight calculation of factors. The multi-influencing factors for groundwater potential zones, namely lineaments, land use, lithology, drainage, slope, soil, rainfall and geomorphology, were considered and assigned an appropriate weight and are shown in Table 1. The effect of each influencing factor may involve delineating of groundwater po-
Ta ble 1

Calculation of effects and rates of factors that affect groundwater potentiality

\begin{tabular}{|l|c|c|c|}
\hline \multicolumn{1}{|c|}{ Factor } & Major effect & Minor effect & Rates \\
\hline Lineaments & 2 & 0 & 2.0 \\
\hline Land use & 1 & 1 & 1.5 \\
\hline Lithology & 4 & 0 & 4.0 \\
\hline Drainage & 1 & 1 & 1.5 \\
\hline Slope & 2 & 1 & 2.5 \\
\hline Soil & 1 & 0 & 1.0 \\
\hline Rainfall & 1 & 1 & 1.5 \\
\hline Geomorphology & 2 & 0 & 2.0 \\
\hline TOTAL & 14 & 4 & 16 \\
\hline
\end{tabular}

tential areas. According to Shaban et al., (2006), each of contributing factors has a degree of influence and effect on others; there can be a major effect, minor effect, or no effect at all. Furthermore, these factors are interrelated. The effect of each major and minor factor is assigned a weightage of 1.0 and 0.5 , respectively (Fig. 3).

The cumulative weightage of both major and minor effects is considered for calculating the relative rates (Table 1). This rate is further used to calculate the score of each influencing factor (Magesh et al., 2012). The proposed score for each influencing factor is calculated by using the mathematical Equation 4:

$$
\text { Score assigned }=\frac{(\text { Major effect }+ \text { Minor effect })}{\Sigma(\text { Major effect }+ \text { Minor effect })} \times 100
$$

Analytical hierarchy process (AHP). Analytical hierarchy process is a structured technique used for analysing complex problems, where a large number of interrelated objectives or criteria are involved (Saaty, 1980). The weight of each factor is defined using the AHP. The weights of these criteria are defined after they are ranked according to their relative importance.

Therefore, when all factors are sorted in a hierarchical manner, a pairwise comparison matrix for each factor is established to enable an importance comparison. The relative importance between the criteria is evaluated from 1 to 9 , indicating less important to much more important criteria (Table 2; Saaty, 1990). However, weighting by AHP is widely used in many applications and is recommended to be used for regional studies (Kazakis et al., 2015).

The proposed methodology suggests a pairwise comparison, using an $8 \times 8$ matrix, where diagonal elements are equal to 1 . Consequently, all the groundwater influencing factors are

T a ble 2

Calculation of effects and rates of factors that affect groundwater potentiality (Saaty, 1990)

\begin{tabular}{|l|c|}
\hline \multicolumn{1}{|c|}{ Option } & Numerical value(s) \\
\hline Equal & 1 \\
\hline Marginally strong & 3 \\
\hline Strong & 5 \\
\hline Very strong & 7 \\
\hline Extremely strong & 9 \\
\hline Intermediate values & $2,4,6,8$ \\
\hline $\begin{array}{l}\text { Reflecting dominance of second alternative } \\
\text { compared with the first }\end{array}$ & Reciprocals \\
\hline
\end{tabular}


Table 3

Pairwise comparison matrix

\begin{tabular}{|l|c|c|c|c|c|c|c|c|}
\hline Factor & $L G$ & $S L$ & $L D$ & $G M$ & $L U$ & $D D$ & $R F$ & $S O$ \\
\hline$L G$ & $9 / 9$ & $9 / 7$ & $9 / 5$ & $9 / 5$ & $9 / 3$ & $9 / 3$ & $9 / 3$ & $9 / 1$ \\
\hline$S L$ & $7 / 9$ & $7 / 7$ & $7 / 5$ & $7 / 5$ & $7 / 3$ & $7 / 3$ & $7 / 3$ & $7 / 1$ \\
\hline$L D$ & $5 / 9$ & $5 / 7$ & $5 / 5$ & $5 / 5$ & $5 / 3$ & $5 / 3$ & $5 / 3$ & $5 / 1$ \\
\hline$G M$ & $5 / 9$ & $5 / 7$ & $5 / 5$ & $5 / 5$ & $5 / 3$ & $5 / 3$ & $5 / 3$ & $5 / 1$ \\
\hline$L U$ & $3 / 9$ & $3 / 7$ & $3 / 5$ & $3 / 5$ & $3 / 3$ & $3 / 3$ & $3 / 3$ & $3 / 1$ \\
\hline$D D$ & $3 / 9$ & $3 / 7$ & $3 / 5$ & $3 / 5$ & $3 / 3$ & $3 / 3$ & $3 / 3$ & $3 / 1$ \\
\hline$R F$ & $3 / 9$ & $3 / 7$ & $3 / 5$ & $3 / 5$ & $3 / 3$ & $3 / 3$ & $3 / 3$ & $3 / 1$ \\
\hline$S O$ & $1 / 9$ & $1 / 7$ & $1 / 5$ & $1 / 5$ & $1 / 3$ & $1 / 3$ & $1 / 3$ & $1 / 1$ \\
\hline
\end{tabular}

Table 4

Calculation of normalized weight parameters of groundwater potentiality index

\begin{tabular}{|l|l|l|l|l|l|l|l|c|}
\hline Factor & $L G$ & $S L$ & $L D$ & $G M$ & $L U$ & $D D$ & $R F$ & $S O$ \\
\hline$L G$ & 1 & 1.28 & 2 & 2 & 3 & 3 & 3 & 9 \\
\hline$S L$ & 0.8 & 1 & 1.4 & 1.4 & 2.33 & 2.33 & 2.33 & 7 \\
\hline$L D$ & 0.6 & 0.71 & 1 & 1 & 1.7 & 1.7 & 1.7 & 5 \\
\hline$G M$ & 0.6 & 0.71 & 1 & 1 & 1.7 & 1.7 & 1.7 & 5 \\
\hline$L U$ & 0.33 & 0.43 & 0.6 & 0.6 & 1 & 1 & 1 & 3 \\
\hline$D D$ & 0.33 & 0.43 & 0.6 & 0.6 & 1 & 1 & 1 & 3 \\
\hline$R F$ & 0.33 & 0.43 & 0.6 & 0.6 & 1 & 1 & 1 & 3 \\
\hline$S O$ & 0.11 & 0.14 & 0.2 & 0.2 & 0.33 & 0.33 & 0.33 & 1 \\
\hline
\end{tabular}

compared against each other in a pairwise comparison matrix (Razandi et al., 2015). The values of each row characterize the importance between two parameters (Tables 3 and 4). The first row of the table illustrates the importance of flow accumulation as regards the other parameters which are placed in the columns (Kazakis et al., 2015).

To evaluate the matrix of the AHP, we computed the consistency ratio $(C R)$ using the following Equation 5:

$$
C R=\frac{C l}{R I}
$$

where: $R I$ - the random index whose value depend on the order of the matrix; $\mathrm{Cl}$ - the consistency index which can be obtained as (6):

$$
C l=\frac{\lambda_{\max }-n}{n-1}
$$

where: $\lambda$ - the largest eigenvalue of the matrix and can be easily determined from the mentioned matrix; $n$ - the number of groundwater conditioning factors. According to Saaty (1980), the consistency ratio $(C R)$ must be $<0.1$.

Consequently, all the conditioning factors are compared against each other in a pairwise comparison matrix.

To determine the assigned rank of different features of influencing factors, we classified them into 10 classes according to the description of each factor based on literature review (Shahid et al., 2000; Shaban et al., 2006; Kourgialas and Karatzas, 2011).

\section{RESULTS AND DISCUSSION}

\section{INFLUENCING FACTORS MAPS}

Lineaments $(L D)$. Statistical processing of lineaments enumerates 1,053 lineaments. The spatial distribution shows high general density of lineaments in structure centres. At some localities, it reached 2.5 lineaments per $1 \mathrm{~km}^{2}$. The lineaments density decreases progressively away from the centres of structures; even it is folded and structured domain (Fig. 4A).

The rose diagram (Fig. 5) shows clear dominance of a NE-SW major direction of lineaments. Representation of lineaments was made by grouping directional families with $10^{\circ}$ class. This major direction of lineaments have the same axis folds direction of study area folded structures. These structures have a general direction of ENE-WSW to E-W that characterizes the Tunisian Southern Atlas (Zargouni, 1985; Zouari, 1995; Ahmadi, 2006; Msaddek et al., 2016).

The reclassification of the raster lineament-density file followed into four classes, from poor to very good, according to the class boundaries of Table 5 . The lineament density was assigned a weight of $14 \%$ in the calculation of AHP weighting of factors that affect groundwater potentiality (Table 6). It can be noticed that in the white area, where no faults and lineaments exist, the potentiality of groundwater presence is low, in contrast to the yellow - red area, where the probability reaches the maximum level.

Land use (LU). Land use is included in this study as an important factor affecting the groundwater potentiality. The land use category is established using GIS and Remote Sensing in- 


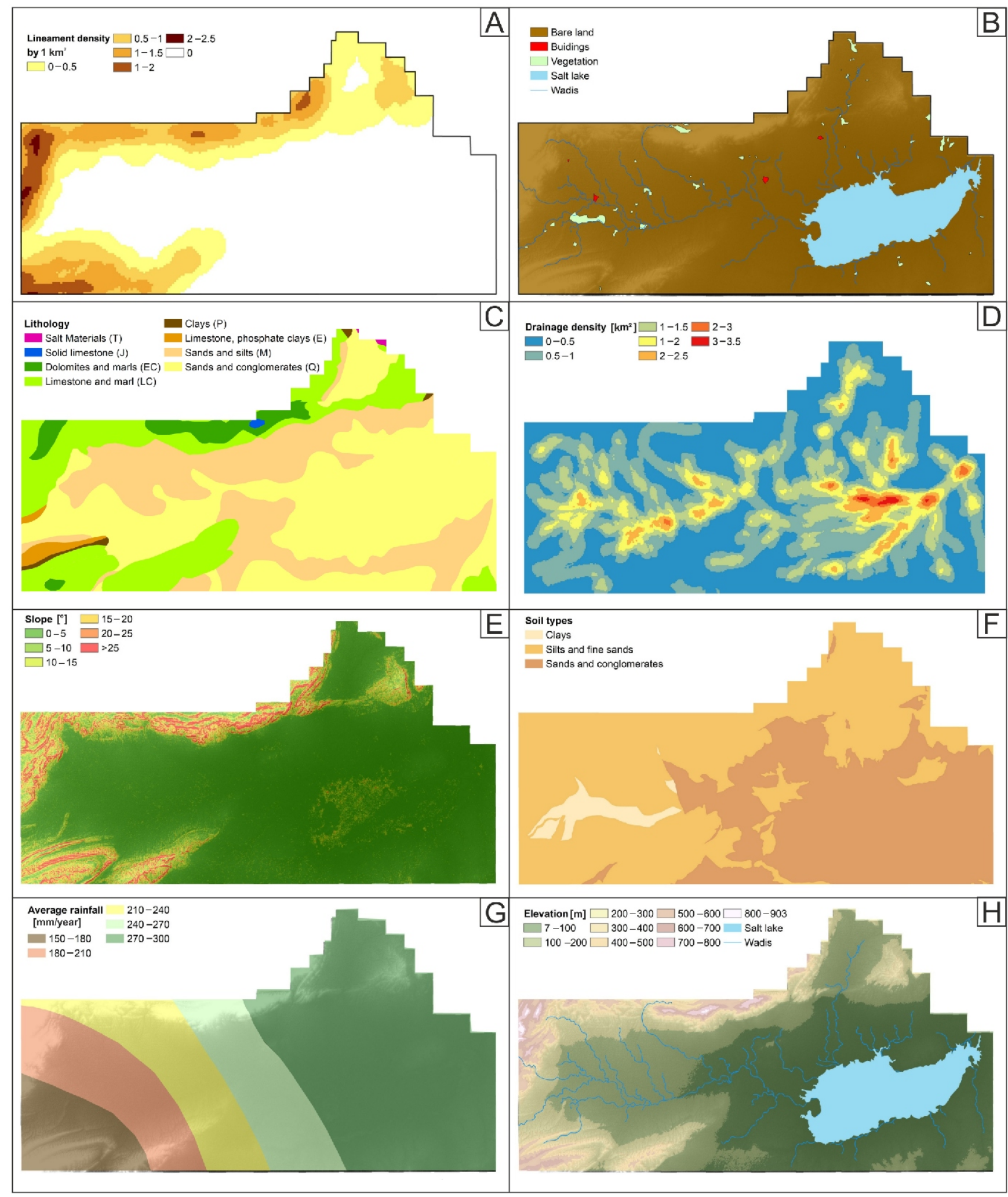

Fig. 4. Groundwater influencing factors

A - lineament density; B - land use; C - lithology of outcrops; D - drainage density; E - slope; F - soil; G - rainfall; H - geomorphology 


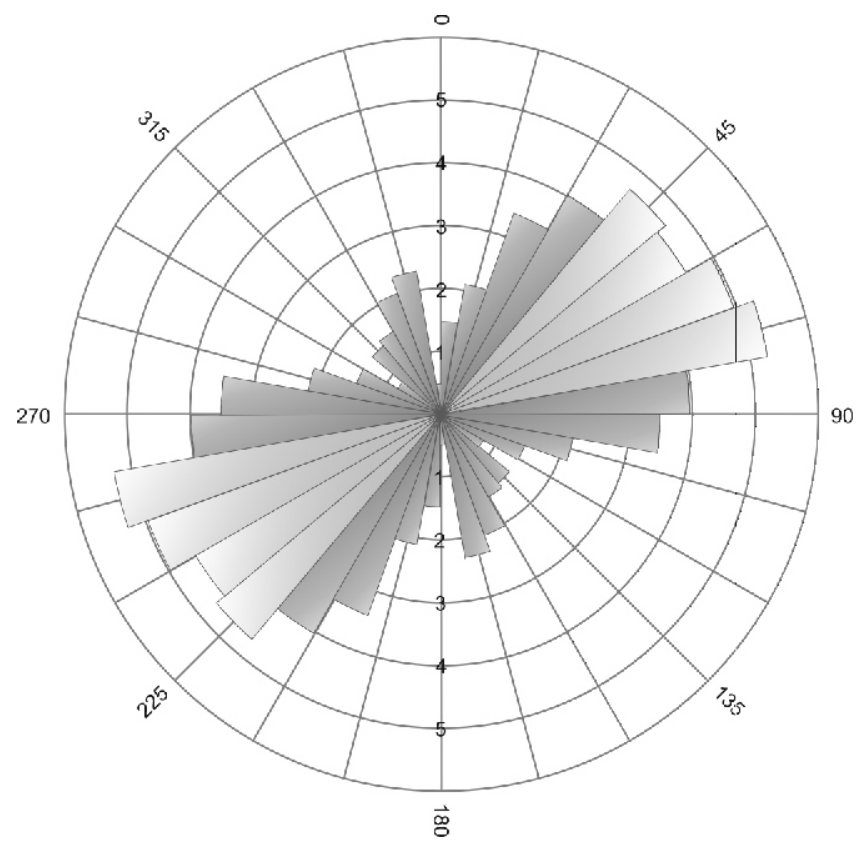

Fig. 5. Rose diagram of lineaments directions

vestigation results provided by the General Department of Water Resources (DGRE) and satellite images. The distribution of land use potential of the study area is shown in Figure 4B. The map indicates that the study area is composed mainly of bare land (no land cover, just small semi-desert steppe; $72 \%$ ), river channel and surface water bodies (25\%), agricultural land and vegetation $(2 \%)$ and buildings $(<1 \%)$. It can be noticed that in the blue area that indicates the existence of water surfaces, the potentiality of groundwater reaches the maximum level. In the brown area that refers to bare land, the potentiality is good.

The classification of the raster land use file followed into four classes, from poor to very good, according to the class boundaries of Table 5. The land use was assigned a weight of $8 \%$ in the calculation of AHP weighting assigned to factors that affect groundwater potentiality (Table 6).

Lithology (LG). In the study area, eight geological units are outcropped. These are Triassic salt materials (T), Jurassic solid limestone (J), Early Cretaceous dolomites and marls (EC), Late Cretaceous marls and fractured limestones (LC). The Paleogene deposits are characterized by abundance of Palaeocene clays $(P)$ and alternations of limestone and phosphate clays of Eocene age $(E)$. The Miocene is represented by sands and silts $(M)$. The Quaternary $(Q)$ is composed of recent sands and conglomerates (Fig. 4C).

The Mio-Plio-Quaternary silts, sands and conglomerates are considered to be water bearing and are an important source of groundwater in the area. Consequently, they are the most productive and widely available aquifer in the region. The Cretaceous fractured limestones are considered a strategic aquifer.

The classification of the raster lithology file followed into four classes, from poor to very good, according to the class boundaries of Table 5. Sands and conglomerates are widely present in the study area, and are considered very good for groundwater potential. Sands and silts are characterized by good groundwater potential. Alternations of carbonates, clays and marls are characterized by moderate infiltration from rainfall. Clays and salts are found in the extreme eastern portion and in the western part of the area, and are generally considered a poor zone for groundwater potential.
The lithology factor was assigned a weight of $25 \%$ in the calculation of AHP weighting assigned to factors that affect groundwater potentiality (Table 6).

Drainage density $(D D)$. The drainage network pattern of the study area is shown in Figure 4D. The classification of the raster drainage density file followed into four classes, from poor to very good, according to the class boundaries of Table 5 . The drainage density was assigned a weight of $8 \%$ in the calculation of AHP weighting assigned to factors that affect groundwater potentiality (Table 6). It can be noticed that in the blue area, where no rivers and wadis exist, the potentiality of groundwater presence is low, in contrast to the yellow - red area, where the probability reaches the maximum level.

Slope $(S L)$. A slope map prepared from the digital elevation model of SRTM of the study area is shown in Figure 4E. The slope percentage in the area varies from 0 to $25 \%$, but it can reach $68 \%$ at some localities especially in the mountainous zone. According to these results, as shown in Table 5, the study area can be divided into four slope classes. The areas having 0 to $5 \%$ slope fall into the "very good" category because of the nearly flat terrain and a relatively high infiltration rate. Most of the study area $(75 \%)$ falls under this category. The areas with 5 to $15 \%$ slope are considered "good" for groundwater storage due to slightly undulating topography with some runoff. The areas having 15 to $25 \%$ of slope cause relatively high runoff and low infiltration, and hence are categorized as "moderate". The fourth (>25\%) category is considered "poor" due to higher slope and runoff.

The slope factor was assigned a weight of $19 \%$ in the calculation of AHP weighting assigned to factors that affect groundwater potentiality (Table 6). It can be noticed that in the orangered area, where the slope percentage is important, the potentiality groundwater presence is low, in contrast to the green area, where the probability reaches the maximum level.

Soil (SO). The analysis of the soil type reveals that the study area is covered predominantly by silts and fine sands in its northern part (54.6\%), sands and conglomerates in its southern part $(42.4 \%)$ and clays (3\%) in its western part (Fig. 4F).

The classification of the soil type followed into three classes; poor, moderate and very good, according to the class boundaries of Table 5 . The soil factor was assigned weight of $3 \%$ in the calculation of AHP weighting assigned to factors that affect groundwater potentiality (Table 6).

Rainfall $(R F)$. For the present study, monthly rainfall data were collected from three stations in the study area during 25 years from 1990 to 2015 . The mean annual rainfall ranges from 150 to $300 \mathrm{~mm}$. The resulting map shows five classes with two major groundwater potential "good" and "moderate" (Table 5 and Fig. 4G): 270-300 mm/y (good), 240-270 mm/y (good), 210-240 mm/y (moderate), 180-210 mm/y (moderate), and 150-180 mm/y (moderate).

The rainfall factor was assigned a weight of $8 \%$ in the calculation of AHP weighting assigned to factors that affect groundwater potentiality (Table 6). It can be noticed that in the brown area, the potentiality of groundwater presence is low, in contrast to the green area, where the probability reaches the maximum level.

Geomorphology (GM). Based on the physiographic characteristics, the landforms of the study area (Fig. 4H) can be classigied into three different units (Table 5) namely: (1) waterbodies, rivers and wadis are considered very good for groundwater potential; (2) plains and lowlands where the elevation is between $7(\mathrm{~m})$ and $200(\mathrm{~m})$ above mean sea level are characterized by very good groundwater potential; (3) mountains and high landforms where the elevation is between 200 
Classification of various factors for groundwater potential zones

\begin{tabular}{|c|c|c|c|}
\hline Factor & Domain of effect & Groundwater potential & Assigned rank \\
\hline \multirow{4}{*}{ Lithology (LG) } & clays and salts & poor & 2 \\
\hline & alternation carbonates/clays/marls & moderate & 5 \\
\hline & sands and silts & good & 8 \\
\hline & sands and conglomerates & very good & 10 \\
\hline \multirow{4}{*}{ Slope $(S L)$} & $>25^{\circ}$ & poor & 2 \\
\hline & $15-25^{\circ}$ & moderate & 5 \\
\hline & $5-15^{\circ}$ & good & 8 \\
\hline & $0-5^{\circ}$ & very good & 10 \\
\hline \multirow{3}{*}{$\begin{array}{c}\text { Geomorphology (GM) } \\
{[\mathrm{m}]}\end{array}$} & $7-200$ & very good & 10 \\
\hline & 200-903 & moderate & 5 \\
\hline & Wadis & very good & 10 \\
\hline \multirow{4}{*}{$\begin{array}{l}\text { Lineaments density }(L D) \\
\left.\text { [per } 1 \mathrm{~km}^{2}\right]\end{array}$} & $0-1$ & poor & 2 \\
\hline & $1-1.5$ & moderate & 5 \\
\hline & $1.5-2$ & good & 8 \\
\hline & $2-2.5$ & very good & 10 \\
\hline \multirow{5}{*}{ Rainfall $(R F)$} & 150-180 (mm/an) & moderate & 5 \\
\hline & $180-210$ & moderate & 5 \\
\hline & $210-240$ & moderate & 5 \\
\hline & $240-270$ & good & 8 \\
\hline & $270-300$ & good & 8 \\
\hline \multirow{4}{*}{$\begin{array}{c}\text { Drainage density }(D D) \\
{\left[\mathrm{km}^{2}\right]}\end{array}$} & $0-1$ & poor & 2 \\
\hline & $1-2$ & moderate & 5 \\
\hline & $2-3$ & good & 8 \\
\hline & $3-3.5$ & very good & 10 \\
\hline \multirow{4}{*}{ Land use $(L U)$} & building & poor & 2 \\
\hline & vegetation & moderate & 5 \\
\hline & bare land & good & 8 \\
\hline & water surface & very good & 10 \\
\hline \multirow{3}{*}{ Soil (SO) } & argillaceous & poor & 2 \\
\hline & silty and fine sandy & moderate & 5 \\
\hline & sandy and conglomeratic & very good & 10 \\
\hline
\end{tabular}

Table 6

Weighting calculation of influencing factors

\begin{tabular}{|l|c|c|c|c|c|c|}
\hline \multirow{2}{*}{ Factors } & \multicolumn{2}{|c|}{ AHP weight } & \multicolumn{4}{c|}{ Effective weighting [\%] } \\
\cline { 2 - 7 } & $\begin{array}{c}\text { theoretical } \\
\text { weighting }\end{array}$ & $\begin{array}{c}\text { theoretical } \\
\text { weighting }[\%]\end{array}$ & max. & min. & mean $[\mu]$ & $\begin{array}{c}\text { standard deviation } \\
(\text { SD) }\end{array}$ \\
\hline$L G$ & 0.25 & 25 & 25 & 5 & 23.56 & 8.75 \\
\hline$S L$ & 0.19 & 19 & 19 & 3.8 & 18 & 6.65 \\
\hline$G M$ & 0.14 & 14 & 14 & 7 & 17.67 & 4 \\
\hline$L D$ & 0.14 & 14 & 14 & 2.8 & 15 & 5 \\
\hline$R F$ & 0.08 & 8 & 6.4 & 4 & 7.55 & 1.3 \\
\hline$D D$ & 0.08 & 8 & 8 & 1.6 & 7.55 & 1.3 \\
\hline$L U$ & 0.08 & 8 & 8 & 1.6 & 7.55 & 1.3 \\
\hline$S O$ & 0.03 & 3 & 3 & 0.6 & 3 & 1.2 \\
\hline
\end{tabular}


and $903 \mathrm{~m}$ in the study area are generally considered a moderate zone for groundwater potential.

The geomorphology was assigned a weight of $14 \%$ in the calculation of AHP weighting assigned to factors that affect groundwater potentiality (Table 6).

\section{WEIGHTS DETERMINATION USING AHP}

To determine the relative importance values, the authors used Saaty's analytical hierarchy process (AHP) with a scale from 1 to 9 , where a score of 1 represents equal importance between the two factors, and a score of 9 indicates the extreme importance of one factor compared to the other. Table 3 shows a matrix for comparing the classes in order to achieve the priority. The weights assigned to different thematic layers are summarized in Table 4.

The AHP captures the idea of uncertainty in judgements through the principal eigenvalue and the consistency index (Saaty 1990).

To calculate the consistency of the pairwise comparison matrix, we used Equation 5 for the measurement of consistency ratio $(C R)$. Two parameters must be calculated, which are $\mathrm{Cl}$ and $R I$.

For the values of Table $4, R I=1.41$ and $C l$ was calculated according to Equation 6, for: $\lambda_{\max }=8.32, n=8$

Eventually, $\mathrm{Cl}=0.06$ and the consistency ratio $C R=0.04$. Since the $C R$ value is lower than the threshold $(0.1)$, the weights' consistency is affirmed.

To proceed the classification of various factors for groundwater potential zones shown in Table 5, each factor was divided within their domain of effect and the weighted rating was assigned for each domain based on weightage calculation of factors shown in Tables 3 and 4. All factors have groundwater potential classification from poor to very good within their domain of effect (Shahid et al., 2000; Shaban et al., 2006; Kourgialas and Karatzas, 2011).

The authors have coupled the AHP with a sensitivity analysis process that evaluates the impact of each criterion on the method to determine the sensitivity of factors to the weights changing. In the sensitivity analysis, the initial arbitrary values of the indexes that AHP uses are replaced with some derivative indexes, the "effective weights" calculated from the following Equation 7:

$$
W=\frac{P_{r} \times P_{w}}{V} \times 100
$$

where: $W$ - effective weight of each parameter; $P_{r}$ - parameter's rating; $P_{w}$ - parameter's weight; $V$-aggregated value of the applied index.

The "effective" weights are the functions of the eight parameters as well as the weight assigned to it by the theoretical AHP. The effective weights (Table 6) are used to calculate the revised theoretical AHP weights. However, the sensitivity analysis shows that there is a slight variation in the values of the weights, and the intensity of importance of each parameter does not change. It reveals that the lithology, slope and geomorphology have a greater influence on the groundwater potential in the studied region.

\section{MAP OF GROUNDWATER POTENTIAL ZONES}

The groundwater potential zones for the study area were generated through the integration of various thematic maps of lineaments, land use, lithology, drainage, slope, soil, rainfall and geomorphology using remote sensing and GIS techniques. The demarcation of groundwater potential zones for the study area was made by grouping the interpreted layers through the weighted multi-influencing factor and finally assigned different potential zones.

The groundwater potential zone of the study area can be divided into four grades, namely very good, good, moderate and poor. The groundwater potential map (Fig. 6) demonstrates that the excellent groundwater potential zone is concentrated mainly in the eastern region of the study area due to the distribution of alluvial plains and agricultural land with high infiltration ability. Figure 7 shows the surface in $\left(\mathrm{km}^{2}\right)$ and $(\%)$ for each groundwater potential zone. It shows that $>50 \%$ have a good to very good potential.

The total of weighted rating of each factor was used in the mathematical Equation 1 of the weighted linear combination method (WLC) to calculate groundwater potentiality index:

$I p=0.25 \times 9+0.19 \times 7+0.14 \times 5+0.14 \times 5+0.08 \times 3+$ $0.08 \times 3+0.08 \times 3+0.03 \times 1=2.25+1.33+0.7+0.7+0.24+$ $0.24+0.24+0.03=5.73$

This index permitted to calculate the effect of the factors on groundwater capacity (Fig. 8). It indicates that lithology and slope play a vital role in groundwater potential with $39.27 \%$ and $23.21 \%$ in the groundwater capacity, respectively. Moreover, geomorphology and lineament density also help the infiltration ability of the groundwater system with $12.22 \%$ for each one. Rainfall, drainage density and land use have $4.19 \%$ in groundwater potential for each one. Finally, the soil factor has a small effect on groundwater potential with $0.52 \%$.

It is encouraging to compare this figure with that found by Mokadem et al. (2018) who demonstrate mapping and evaluation of groundwater recharge potential in arid environments in Tunisia using a similar method. Authors confirm that the use of a smaller number of influencing parameters decrease the accuracy of results. Chenini and Ben Mammou (2010) applied numerical modelling to validate groundwater recharge potential accuracy in the Meknassy basin, an arid region located in southern Tunisia. They found a broad link between earth surface parameters and groundwater potential zones.

Magesh et al. (2012) applied a similar method in Theni district, Tamil Nadu, India. They reported different results on the weighted rating of the influencing factors. They show that the soil has a vital role in groundwater augmentation. In the current study, the soil has a minor effect on groundwater potential. Kumar et al. (2014) found a different weighted rating for the influencing factors in the Durg district, India. The same conclusion was reported by Machiwal et al. (2011) in a semi-arid region in India. The comparison with those works shows that the impact of factors on groundwater potential may depend on site-specific features and user's definitions of weights and rates.

The proposed methods for the estimation of groundwater potential zones are a powerful tool that helps on decision-making. It respect closely the characteristic and the different criteria of any study area. It can be a useful tool for the planning against overexploitation, and for the water resources management, supply and optimization.

Although widely accepted, this method suffers from some limitations due to the uses of an extensive database and large statistical information. Thus, the results can vary according to the quantity of data used. However, this method does involve a potential measurement error.

The proposed approach is useful in other case studies in different climates, such as humid regions. Result depends on site-specific features and user's definitions of weights and rates. The influencing factors and their weights and rates vary from one region to another. 


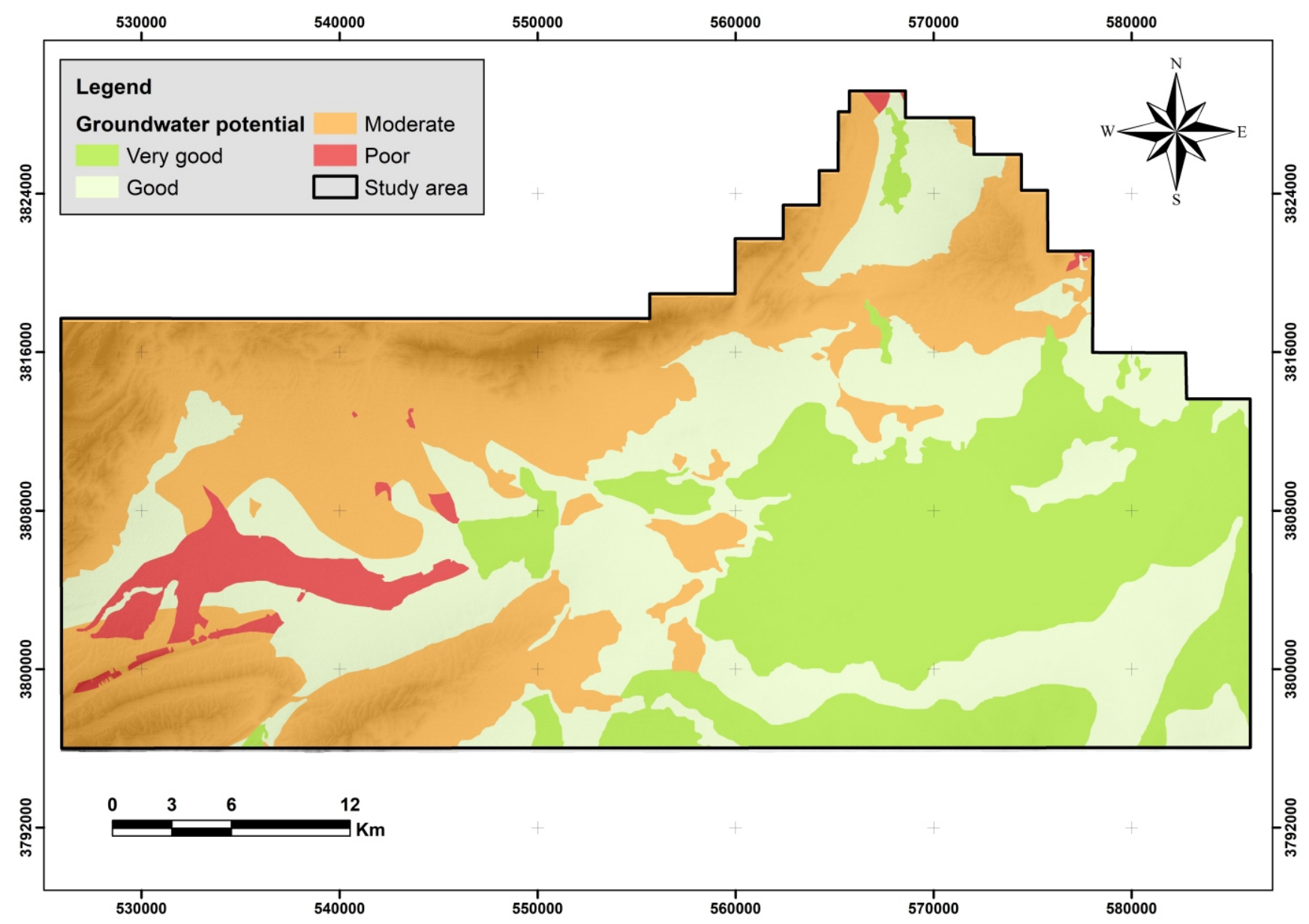

Fig. 6. Groundwater potential zone map of the Bouhedma region

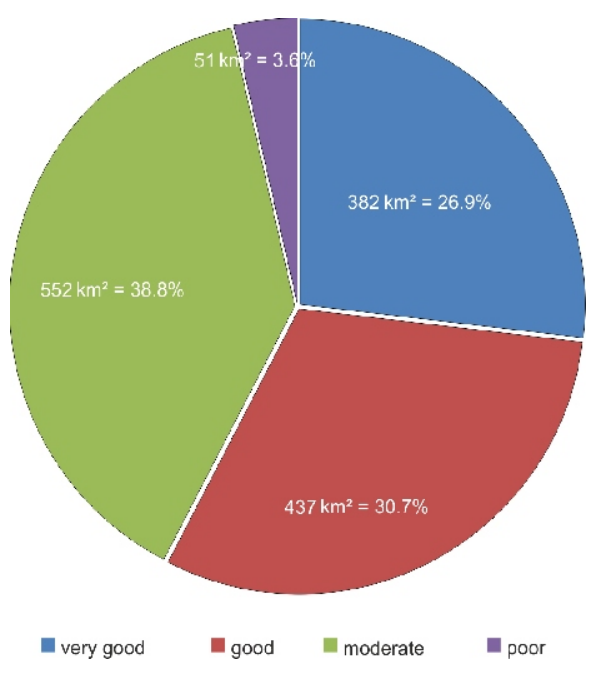

Fig. 7. Pie chart for the distribution of groundwater potential zones

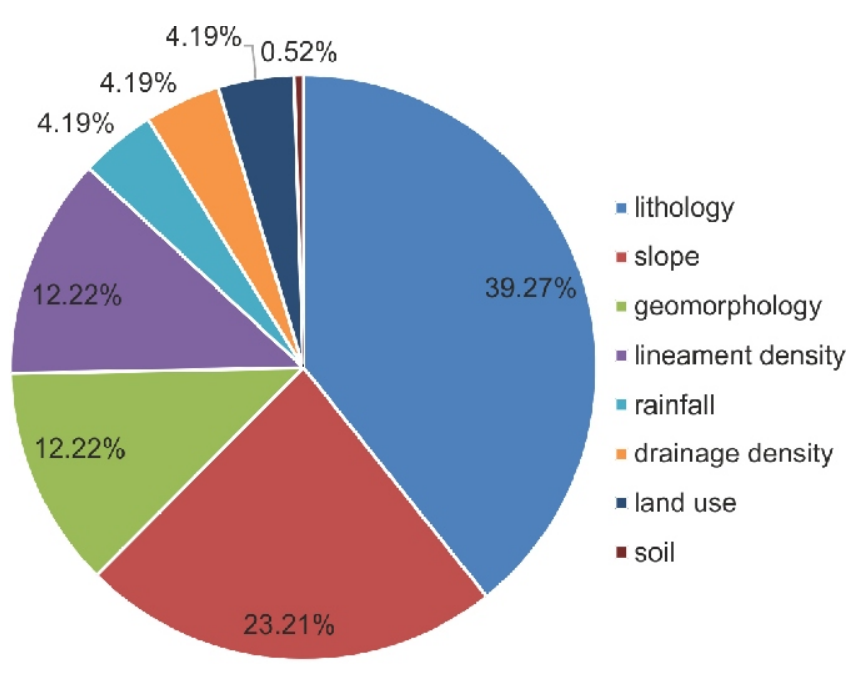

Fig. 8. Pie chart for the effect of factors on groundwater capacity 


\section{CONCLUSION}

This study adopts Saaty's method based on multi-criteria evaluation, analytic hierarchy process (AHP), Remote Sensing and GIS, and was applied to assess the groundwater potentiality in the Bouhedma region, southwestern Tunisia. Eight parameters with different weights (lineaments, land use, lithology, drainage, slope, soil, rainfall and geomorphology) were used, resulting in a final map based on weighted linear combination. Statistical sensitivity analysis on the values assigned to the different criteria validates the efficiency of the developed methodology. The Bouhedma area is divided into four different zones, namely; very good, good, moderate, and poor. The results of the study reveal a high groundwater potential (good to very good) in $>50 \%$ of the study area. The effect of each influencing factor on groundwater capacity was computed. The results of the present study can serve as guidelines for planning future artificial recharge projects in the study area. The proposed method can be applied in managing groundwater use, such as in regional groundwater development planning, determination of promising groundwater development areas, and controlling the water-supply system based on a systematic, objective and scientific decision model. In addition, the groundwater potential zone map can greatly help planners seeking suitable locations at which to implement exploration. The method used in this study is also valid for generalized planning and assessment purposes in order to ensure sustainable groundwater utilization. However, this method might be more useful if it is combined with a complementary hydrogeological study, such as aquifer geometry, piezometry and groundwater geochemistry. The versatility of the method can integrate different parameters and factors and redefine easily their weights, so the method could be applied in a wider variety of regions. It respect closely the characteristic and the different criteria of any study area.

Acknowledgements. Remotely sensed data and SRTM were available from the U.S. Geological Survey. The research was supported by Tunisian Ministry of Higher Education and Tunis El Manar University with the collaboration of the University of Mouloud Mammeri of Tizi-Ouzou (Algeria).

\section{REFERENCES}

Agarwal, C.S., 1998. Study of drainage pattern through aerial data in Naugarh area of Varanasi district, UP. Journal of the Indian Society of Remote Sensing, 26: 169-175.

Ahmadi, R., 2006. Utilisation des marqueurs morphologiques, sédimentologiques et microstructuraux pour la validation des modèles cinématiques de plissement (in French). Application à l'Atlas méridional tunisien. Ph.D. thesis. Université des Sciences et des Techniques de Nantes.

Al-Adamat, R.A., Foster, I.D., Baban, S.M., 2003. Groundwater vulnerability and risk mapping for the Basaltic aquifer of the Azraq basin of Jordan using GIS, Remote sensing and DRASTIC. Applied Geography, 23: 303-324.

Arnold, J.G., Allen, P.M., Bernhardt, G., 1993. A comprehensive surface-groundwater flow model. Journal of hydrology, 142 47-69.

Becker, M.W., 2006. Potential for satellite remote sensing of ground water. Groundwater, 44: 306-318.

Bencheikh, N., 2013. Etude des relations hydrodynamiques entre la nappe profonde de Sfax et les systèmes aquifères méridionaux (Menzel Habib et Gabès nord): origine(s) et mécanismes de minéralisation des eaux souterraines (in French). Ph.D. thesis, Ecole Nationale d'Ingénieurs de Sfax. $\mathrm{N}^{\circ}$ 280/13.

Blaschke, T., 2010. Object based image analysis for remote sensing. ISPRS journal of photogrammetry and remote sensing, 65 2-16.

Bouwer, H., 2002. Artificial recharge of groundwater: hydrogeology and engineering. Hydrogeology Journal, 10: 121-142.

Chenini, I., Ben Mammou, A., 2010. Groundwater recharge study in arid region: an approach using GIS techniques and numerical modeling. Computers and Geosciences, 36: 801-817.

Chowdhury, A., Jha, M.K., Chowdary, V.M., Mal, B.C., 2009. Integrated remote sensing and GIS-based approach for assessing groundwater potential in West Medinipur district, West Bengal, India. International Journal of Remote Sensing, 30: 231-250.

Dasho, O.A., Ariyibi, E.A., Akinluyi, F.O., Awoyemi, M.O., Adebayo, A.S., 2017. Application of satellite remote sensing to groundwater potential modeling in Ejigbo area, Southwestern Nigeria. Modeling Earth Systems and Environment, 3: 615-633.

Davidson, C.E., Ben-David, A., 2011. On the use of covariance and correlation matrices in hyperspectral detection. In Applied Imagery Pattern Recognition Workshop (AIPR), 2011 IEEE. IEEE.
Dinesh Kumar, P.K., Gopinath, G., Seralathan, P., 2007. Application of remote sensing and GIS for the demarcation of groundwater potential zones of a river basin in Kerala, southwest coast of India. International Journal of Remote Sensing, 28: 5583-5601.

Doell, P., Hoffmann-Dobrev, H., Portmann, F.T., Siebert, S. Eicker, A., Rodell, M., Strassberg, G., Scanlon, B.R., 2012. Impact of water withdrawals from groundwater and surface water on continental water storage variations. Journal of Geodynamics, 59: 143-156.

Fenta, A.A., Kifle, A., Gebreyohannes, T., Hailu, G., 2015. Spatial analysis of groundwater potential using remote sensing and GIS-based multi-criteria evaluation in Raya Valley, northern Ethiopia. Hydrogeology Journal, 23: 195-206.

Finch, J.W., 1998. Estimating direct groundwater recharge using a simple water balance model-sensitivity to land surface parameters. Journal of Hydrology, 211: 112-125.

Ghayoumian, J., Saravi, M.M., Feiznia, S., Nouri, B., Malekian, A., 2007. Application of GIS techniques to determine areas most suitable for artificial groundwater recharge in a coastal aquifer in southern Iran. Journal of Asian Earth Sciences, 30: 364-374.

Gustafsson, P., 1993. High resolution satellite data and GIS as a tool for assessment of the groundwater potential of a semi-arid area. Proceedings of the Thematic Conference on Geologic Remote Sensing, Environmental Research Institute of Michigan, 1: 609-609.

Hamza, S.M., Ahsan, A., Imteaz, M.A., Ghazali, A.H., Mohammed, T.A., 2017. GIS-based FRASTIC model for pollution vulnerability assessment of fractured-rock aquifer systems. Environmental Earth Sciences, 76: 197.

Harbor, J.M., 1994. A practical method for estimating the impact of land-use change on surface runoff, groundwater recharge and wetland hydrology. Journal of the American Planning Association, 60: 95-108.

Hegazy, M.N., Effat, H.A., 2010. Monitoring some environmental impacts of oil industry on coastal zone using different remotely sensed data. The Egyptian Journal of Remote Sensing and Space Science, 13: 63-74.

Henchiri, M., 2007. Sedimentation, depositional environment and diagenesis of Eocene biosiliceous deposits in Gafsa basin (southern Tunisia). Journal of African Earth Sciences, 49: 187-200. 
Jha, M.K., Chowdhury, A., Chowdary, V.M., Peiffer, S., 2007 Groundwater management and development by integrated remote sensing and geographic information systems: prospects and constraints. Water Resources Management, 21: 427-467.

Kadri, A., Essid, E.M., Merzeraud, G., 2015. "Kasserine Island" boundaries variations during the Upper Cretaceous-Eocene (central Tunisia). Journal of African Earth Sciences, 111 244-257.

Kazakis, N., Kougias, I., Patsialis, T., 2015. Assessment of flood hazard areas at a regional scale using an index-based approach and Analytical Hierarchy Process: application in RhodopeEvros region, Greece. Science of the Total Environment, 538: 555-563.

Kourgialas, N.N., Karatzas, G.P., 2011. Flood management and a GIS modelling method to assess flood-hazard areas-a case study. Hydrological Sciences Journal-Journal des Sciences Hydrologiques, 56: 212-225.

Kumar, T., Gautam, A.K., Kumar, T., 2014. Appraising the accuracy of GIS-based Multi-criteria decision making technique for delineation of Groundwater potential zones. Water resources management, 28: 4449-4466.

Leduc, C., Favreau, G., Schroeter, P., 2001. Long-term rise in a Sahelian water-table: the Continental Terminal in south-west Niger. Journal of hydrology, 243: 43-54.

Machiwal, D., Jha, M.K., Mal, B.C., 2011. Assessment of groundwater potential in a semi-arid region of India using remote sensing, GIS and MCDM techniques. Water resources management 25: $1359-1386$.

Magesh, N.S., Chandrasekar, N., Soundranayagam, J.P., 2012 Delineation of groundwater potential zones in Theni district, Tamil Nadu, using remote sensing, GIS and MIF techniques. Geoscience Frontiers, 3: 189-196.

Mamou, A., 1990. Caractéristiques et évaluation des ressources en eau du Sud tunisien (in French). Ph.D. thesis, University of Paris South, France.

Masoud, A., Koike, K., 2006. Tectonic architecture through Landsat-7 ETM+/SRTM DEM-derived lineaments and relationship to the hydrogeologic setting in Siwa region, NW Egypt. Journal of African Earth Sciences, 45: 467-477.

Mokadem, N., Boughariou, E., Mudarra, M., Brahim, F.B. Andreo, B., Hamed, Y., Bouri, S., 2018. Mapping potential zones for groundwater recharge and its evaluation in arid environments using a GIS approach: case study of North Gafsa Basin (Central Tunisia). Journal of African Earth Sciences, 141 107-117.

Msaddek, M.H., 2017. Analyse quantitative et qualitative de la fracturation de la région Bouhedma-Ségui, implication hydrogéologique. Ph.D. thesis, University Tunis El Manar. Fac. Sc. Tunis

Msaddek, M.H., Moumni, Y., Chenini, I., Mercier, E., Dlala, M., 2016. Fractures network analysis and interpretation in carbonate rocks using a multi-criteria statistical approach: case study of Jebal Chamsi and Jebal Belkhir, South-western part of Tunisia. Journal of African Earth Sciences, 123: 99-109.

Msaddek, M.H., Souissi, D., Moumni, Y., Chenini, I., Dlala, M., 2017. Integrated Multi-criteria evaluation and weighted overlay analysis in assessment of groundwater potentiality in Segui Region, Southern Tunisia. In: Euro-Mediterranean Conference for Environmental Integration: 631-632. Springer, Cham.

Mukherjee, P., Singh, C.K., Mukherjee, S., 2012. Delineation of groundwater potential zones in arid region of India - a remote sensing and GIS approach. Water resources management, 26 2643-2672.

Naghibi, S.A., Pourghasemi, H.R., Abbaspour, K., 2018. A comparison between ten advanced and soft computing models for groundwater qanat potential assessment in Iran using R and GIS. Theoretical and Applied Climatology, 131: 967-984.

Oikonomidis, D., Dimogianni, S., Kazakis, N., Voudouris, K., 2015. A GIS/remote sensing-based methodology for groundwa- ter potentiality assessment in Tirnavos area, Greece. Journal of Hydrology, 525: 197-208.

Ozesmi, S.L., Bauer, M.E., 2002. Satellite remote sensing of wetlands. Wetlands ecology and management, 10: 381-402.

Rahman, A., 2008. A GIS based DRASTIC model for assessing groundwater vulnerability in shallow aquifer in Aligarh, India. Applied geography, 28: 32-53.

Rahmati, O., Haghizadeh, A., Stefanidis, S., 2016. Assessing the accuracy of GIS-based analytical hierarchy process for watershed prioritization, Gorganrood River Basin, Iran. Water resources management, 30: 1131-1150.

Razandi, Y., Pourghasemi, H.R., Neisani, N.S., Rahmati, O. 2015. Application of analytical hierarchy process, frequency ratio, and certainty factor models for groundwater potential mapping using GIS. Earth Science Informatics, 8: 867-883.

Saaty, T.L., 1980. The Analytic Hierarchy Process. McGraw Hill, New York.

Saaty, T.L., 1990. How to make a decision: the analytic hierarchy process. European journal of operational research, 48: 9-26.

Saraf, A.K., Choudhury, P.R., 1998. Integrated remote sensing and GIS for groundwater exploration and identification of artificial recharge sites. International journal of Remote sensing, 19: 1825-1841.

Scanlon, B.R., Keese, K.E., Flint, A.L., Flint, L.E., Gaye, C.B., Edmunds, W.M., Simmers, I., 2006. Global synthesis of groundwater recharge in semiarid and arid regions. Hydrological Processes: an International Journal, 20: 3335-3370.

Selvam, S., Dar, F.A., Magesh, N.S., Singaraja, C., Venkatramanan, S., Chung, S.Y., 2016. Application of remote sensing and GIS for delineating groundwater recharge potential zones of Kovilpatti Municipality, Tamil Nadu using IF technique. Earth Science Informatics, 9: 137-150.

Shaban, A., Khawlie, M., Abdallah, C., 2006. Use of remote sensing and GIS to determine recharge potential zones: the case of Occidental Lebanon. Hydrogeology Journal, 14: 433-443.

Shahid, S., Nath, S., Roy, J., 2000. Groundwater potential modelling in a soft rock area using a GIS. International Journal of Remote Sensing, 21: 1919-1924

Šilhavý, J., Minár, J., Mentlík, P., Sládek, J., 2016. A new artefacts resistant method for automatic lineament extraction using Multi-Hillshade Hierarchic Clustering (MHHC). Computers and Geosciences, 92: 9-20.

Sophocleous, M., 2002. Interactions between groundwater and surface water: the state of the science. Hydrogeology journal, 10: $52-67$.

Souissi, D., Msaddek, M.H., Zouhri, L., Chenini, I., El May, M., Dlala, M., 2018. Mapping groundwater recharge potential zones in arid region using GIS and Landsat approaches, southeast Tunisia. Hydrological Sciences Journal, 63: 251-268.

Yao T.K., 2009. Hydrodynamisme dans les aquifères de socle cristallin et cristallophyllien du Sud-Ouest de la Côte d'Ivoire: cas du département de Soubré: apports de la télédétection, de la géomorphologie et de l'hydrogéochimie (in French). Océan, Atmosphère. Conservatoire national des arts et métiers CNAM; Université de Cocody - Côte d'Ivoire.

Yeh, H.F., Lee, C.H., Hsu, K.C., Chang, P.H., 2009. GIS for the assessment of the groundwater recharge potential zone. Environmental geology, 58: 185-195.

Zargouni, F., 1985. Tectonique de l'Atlas méridional de Tunisie. Evolution géométrique et cinématique des structures en zones de cisaillement (in French). Msc. thesis, Univ. Louis Pasteur, Strasbourg, France.

Zouaghi, T., Ferhi, I., Bédir, M., Youssef, M.B., Gasmi, M., Inoubli, M.H., 2011. Analysis of Cretaceous (Aptian) strata in central Tunisia, using 2D seismic data and well logs. Journal of African Earth Sciences, 61: 38-61.

Zouari, H., 1995. Evolution géodynamique de l'Atlas centroméridional de la Tunisie. Stratigraphie, analyses géométrique, cinématique et tectono-sédimentaire (in French). Msc. thesis, Univ. Tunis II, Tunisia. 